\title{
Application of Design Methodology for Education
}

\author{
W. Ernst Eder, \\ Professor (Retired), Mechanical Engineering, Royal Military College of Canada \\ Home: 107 Rideau Street, Kingston, ON K7K 7B2, (613) 547-5872 \\ eder-e@rmc.ca
}

\begin{abstract}
Designing is anticipating and establishing a product to fulfill a need. Design engineering is a function of industry offering technical systems. It involves iterative and recursive processing, a design specification, searching for solutions, evaluating, decision-making, and communicating, supported by obtaining and preparing information, verifying, checking, reflecting, and representing. The steps can be performed intuitively and/or systematically, using various methods, feedback, iteration and recursion.

Engineering curricula should expose students to design methodology and theory to develop the ability and skill for designing. This exposure should occur for the whole class, not just by separate attention to individual students.
\end{abstract}

\section{Introduction}

Designing is a process and human activity of antici-pating a future and establishing how it is likely to be achieved, especially by creating a product (that will be made by an enterprise) to fulfill a recognized need of some human group. The need may be for something visually, esthetically and/or ergonomically suitable and pleasing - industrial design - at one end of a 'scale' of products. Alternatively the need may be for something that works, does a job, usually with a substantial engineering content, designing technical processes and technical systems - design engineering. In most cases, both design engineering and industrial design should be actively involved. Products, as defined by ISO9000:2000 [1], include goods and services, artifacts and processes, information (including data and knowledge [2], etc.

Designing for these two extremes of industrial design and design engineering shows several typical differences in many aspects. A caricature is shown in table 1. Architecture involves artistic (industrial) designing of large-scale buildings, and in addition the responsibilities of the legal and contractual negotiations, and progress management of the project. All 'details' of civil engineering structural integrity and conformance to codes, internal services (water, electrical power, heating/ventilating/air-conditioning, etc.) are delegated to engineering contractors, who assume the professional responsibility, and the legal liability. Industrial design is mainly involved in achieving the satisfaction of customers for quantity-produced consumer goods and consumer durables that must fit into an esthetic scheme envisioned by that customer. If the product needs to function, to do something useful, to drive a process,
Table 1 Characteristics of Designing [3]

\begin{tabular}{|l|l|l|}
\hline $\begin{array}{l}\text { Research } \\
\text { Objectives, } \\
\text { Design } \\
\text { Conditions }\end{array}$ & $\begin{array}{l}\text { Design } \\
\text { Engineering }\end{array}$ & $\begin{array}{l}\text { Artistic- } \\
\text { Architectural } \\
\text { - Industrial } \\
\text { Design }\end{array}$ \\
\hline $\begin{array}{l}\text { The object to } \\
\text { be designed, or } \\
\text { the existing } \\
\text { (designed) } \\
\text { object }\end{array}$ & $\begin{array}{l}\text { Technical } \\
\text { System; } \\
\text { primary: } \\
\text { functioning, } \\
\text { perform a task }\end{array}$ & $\begin{array}{l}\text { Product; } \\
\text { primary: } \\
\text { appearance, } \\
\text { functionality }\end{array}$ \\
\hline $\begin{array}{l}\text { Representation } \\
\text { and analysis of } \\
\text { the object as } \\
\text { designed, and } \\
\text { its 'captured } \\
\text { design intent' }\end{array}$ & $\begin{array}{l}\text { Preparing for } \\
\text { manufacture, } \\
\text { assembly, } \\
\text { distribution, } \\
\text { etc., AI, } \\
\text { CAD/CAM }\end{array}$ & $\begin{array}{l}\text { Rendering for } \\
\text { presentation } \\
\text { and display, } \\
\text { product range } \\
\text { decisions }\end{array}$ \\
\hline $\begin{array}{l}\text { Design process } \\
\text { (for the object), } \\
\text { methodology,- } \\
\text { generating the } \\
\text { 'design intent' }\end{array}$ & $\begin{array}{l}\text { Theories of } \\
\text { designing, } \\
\text { Design Science, } \\
\text { Formal design } \\
\text { methodologies }\end{array}$ & $\begin{array}{l}\text { Intuitive, } \\
\text { collaborative, } \\
\text { interactive } \\
\text { designing }\end{array}$ \\
\hline $\begin{array}{l}\text { Design } \\
\text { phenomenology }\end{array}$ & $\begin{array}{l}\text { Empirical, } \\
\text { experimental } \\
\text { and } \\
\text { implementation } \\
\text { studies }\end{array}$ & $\begin{array}{l}\text { Protocol } \\
\text { studies }\end{array}$ \\
\hline $\begin{array}{l}\text { Location } \\
\text { Responsibilities }\end{array}$ & $\begin{array}{l}\text { Professional, } \\
\text { reliability, } \\
\text { liability, safety, } \\
\text { public, } \\
\text { organization, } \\
\text { stakeholders }\end{array}$ & $\begin{array}{l}\text { Design/ } \\
\text { Drawing Office } \\
\text { stakeholders }\end{array}$ \\
\hline Studio \\
\hline
\end{tabular}

design engineering is an essential task.

\section{Design Engineering}

Design engineering has responsibilities beyond customer satisfaction, including safety of the technical product, safety for humans, reduced hazard for the environment, conforming to laws and regulations, delivering 


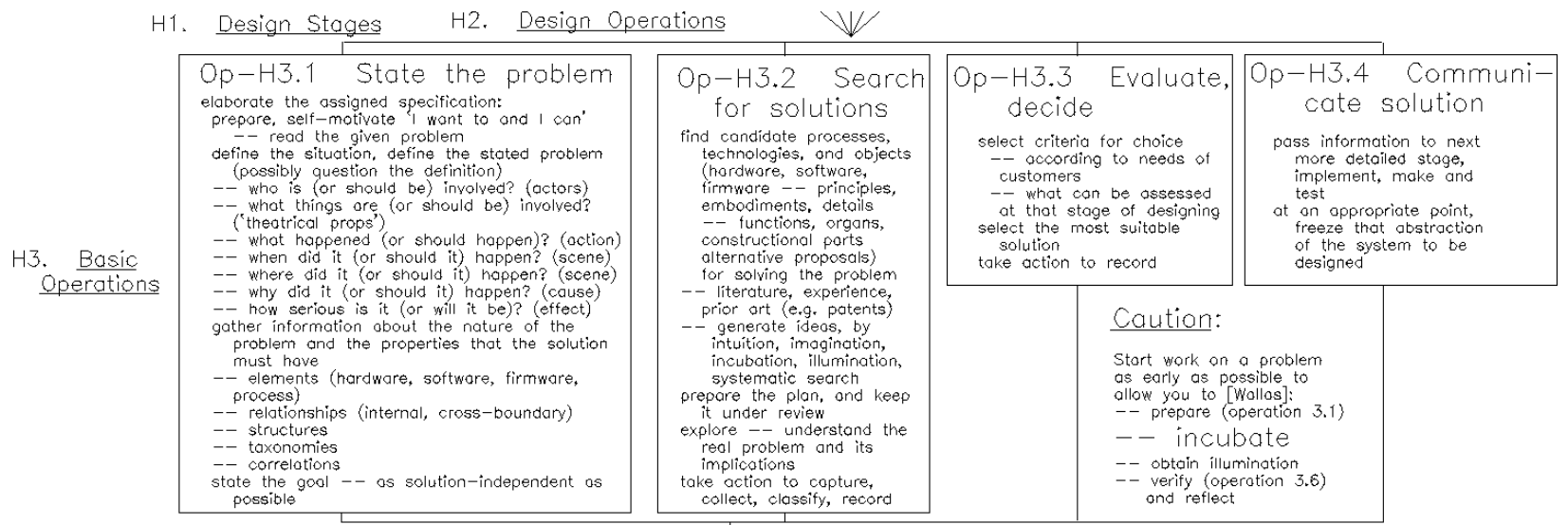

\begin{tabular}{|c|c|c|c|}
\hline $\begin{array}{l}\text { Op-H3.5 Prepare } \\
\text { information } \\
\text { gathering, copturing, } \\
\text { extrocting, sorting, } \\
\text { classifyng, cross- } \\
\text { referencing, modifying } \\
\text { according to designn } \\
\text { needs } \\
\text { (see also figure EX-2) }\end{array}$ & $\begin{array}{l}\text { Op-H3. } 6 \text { Verify, } \\
\text { check, reflect } \\
\text { test the solutions } \\
-- \text { rorital experiment } \\
-- \text { order-of-magnitude } \\
\text { colculations } \\
\text {-- annolysis, simulation } \\
\text { check for possible } \\
\text { improvements, especially } \\
\text { of unsatisfactory elements } \\
\text { look bock - establish whot } \\
\text { has been learned from the } \\
\text { solution attempt -- design } \\
\text { process and object } \\
\text { knowledge, experience }\end{array}$ & $\begin{array}{c}\text { Op-H3.7 Represent } \\
\text { e.g. graphical, verbol. } \\
\text { symbolic/mathematical, } \\
\text { physical oppearonce } \\
\text { madel, } \\
\text { physitol functional } \\
\text { model (prototype) }\end{array}$ & 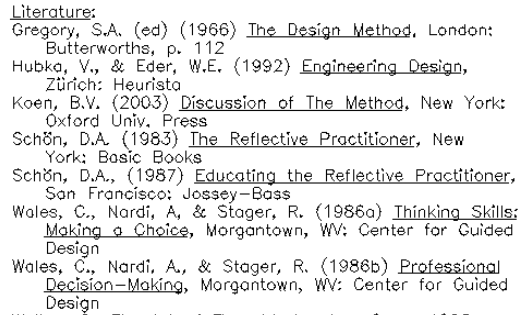 \\
\hline
\end{tabular}

\section{Figure 1 Problem Solving}

acceptable performance, and many others. Design engineering should therefore involve several recognizable procedural stages and steps [4,5] - not necessarily in the prescribed set sequence, but necessarily with iterative and recursive processing. A basic sequence consists of the steps of problem solving, see figure 1: (1) clarifying the problem, e.g. by writing a design specification, (2) searching for candidate solutions, (3) evaluating those candidate solutions to establish the probably optimal (best suited) solution, decision-making, and (4) communicating that solution proposal to a next more detailed level, or to an implementing organization. The steps are supported by (5) obtaining and preparing information, (6) verifying, checking, reflecting, and (7) representing, e.g. by drawings and/or computer-resident digital models. This set of problem solving steps is a recurring pattern in a (hierarchically superior) methodology. Each of these steps can be sub-divided into more explicit instructions (prescriptions).

The steps of problem solving can be performed intuitively and/or systematically, using various methods as appropriate. These steps involve analyzing, in step 1 in verbal form, in step 3 also in mathematical and/or engineering-science form. They also involve synthesizing, in step 2 by searching for principles and precedents, and combining to a whole. Evaluating, using subjective judgment and the objective results of analysis, is the precursor to making decisions. Other essential operations of designing are also present in a more or less formalized way.

In addition to the most concrete modeling and representation of a proposed product (e.g. as a 'solid model' in computers, as a physical model, or as a pictorial rendering - the main models available for industrial design), several more abstract structures can be recognized in technical systems. These can be used to analyze a system, or to assist in synthesizing.

Design engineering is a significant function within the industry concerned with offering technical systems (TS) for use. The main goal of designing is to deliver the finalized description of a technical process and/or technical system, as the subject of designing, the TS(s), in its optimal state (ready for manufacture), in the shortest possible time, and at the lowest possible cost. The optimal state is as close to the state of the art (a) as it exists at that time, and (b) as is considered possible and necessary within the given constraints - of time, cost, perceived quality, user capabilities, cultural and environmental considerations, etc. Cost may be only self-cost of the industry, but should preferably include life-cycle costs.

\section{Design Method - Basis}

The fundamental model of Engineering Design Science $[4,5,6]$ with abstractions for technical systems is that of a general transformation system, figure 2 :

- An operand (materials, energy, information and/or living things) in state Od1 is transformed into state Od2 by applying a suitable technology and using the effects (materials, energy and/or information) exerted by the operators (human systems, technical systems, active environment, information systems, and management systems), whereby assisting inputs are needed $(M, E, I)$, and secondary inputs and outputs can occur (M,E,I), both for the operand and for the operators. 


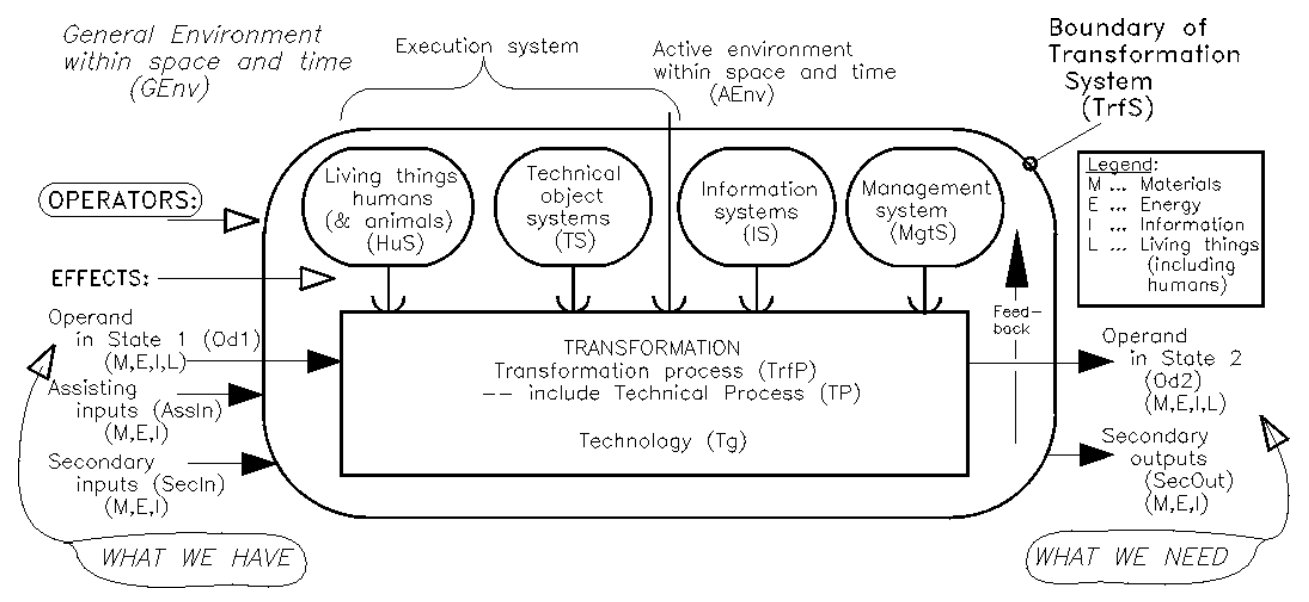

Figure 2 General Model of a Transformation System [4,5,6]

\begin{tabular}{|c|c|c|c|c|c|}
\hline \multirow{2}{*}{\multicolumn{2}{|c|}{$\begin{array}{l}\text { TRANSFORMATION } \\
\text { PROCESS (TrFP) }\end{array}$}} & \multicolumn{4}{|c|}{ TRANSFORMATION } \\
\hline & & of structure & of form & $\begin{array}{l}\text { of space } \\
\text { coordinate }\end{array}$ & $\begin{array}{l}\text { of time } \\
\text { coordinate }\end{array}$ \\
\hline & & PROCESSING & MANUFACTURING & TRANSPORTING & STORING \\
\hline \multirow{8}{*}{$\begin{array}{l}0 \\
\frac{0}{\alpha} \\
\frac{1}{4} \\
\frac{1}{0} \\
0\end{array}$} & $\begin{array}{c}\text { Material } \\
\text { M }\end{array}$ & $\begin{array}{l}M \text { convert } \\
\text { (process) }\end{array}$ & $\begin{array}{l}\text { M tronsform } \\
\text { (form, shape) }\end{array}$ & M tronsport & M store \\
\hline & e.g. & $\begin{array}{l}\text { iron ore } \\
-\rightarrow>\text { steel }\end{array}$ & $\begin{array}{l}\text { scantling } \\
-->\text { workpiece }\end{array}$ & $\begin{array}{l}\text { workpiece in } \\
\text { storage bin } \\
-- \text { wp on } \\
\text { assembly line }\end{array}$ & $\begin{array}{l}\text { workpiece in } \\
\text { storage bin }\end{array}$ \\
\hline & $\begin{array}{c}\text { Energy } \\
\text { E }\end{array}$ & $E$ convert & E transform & E transport & E store \\
\hline & e.g. & $\begin{array}{l}\text { hydraulic } \\
-->\text { electrical }\end{array}$ & $\begin{array}{l}50000 \mathrm{~V} \\
-->220 \mathrm{~V}\end{array}$ & $\begin{array}{l}\text { power station } \\
-->\text { consumer }\end{array}$ & $\begin{array}{l}\text { in accumulator } \\
\text { (battery, spring) }\end{array}$ \\
\hline & $\begin{array}{l}\text { Information } \\
1\end{array}$ & I convert & $\begin{array}{l}\text { 1 transform } \\
\text { (translate) }\end{array}$ & I transport & I store \\
\hline & e.g. & $\begin{array}{l}\text { graphical } \\
-\rightarrow>\text { digital }\end{array}$ & $\begin{array}{l}\text { German text } \\
-->\text { English }\end{array}$ & $\begin{array}{l}\text { news sender } \\
-->\text { receiver }\end{array}$ & $\begin{array}{l}\text { speech on } \\
\text { magnetic tope }\end{array}$ \\
\hline & $\begin{array}{c}\text { Human (animal) } \\
\text { Hu (L) }\end{array}$ & Hu convert & Hu transform & Hu tronsport & Hu store \\
\hline & e.g. & $\begin{array}{l}\text { sick } \\
-\rightarrow>\text { healthy }\end{array}$ & $\begin{array}{l}\text { natural hand } \\
-->\text { prosthesis }\end{array}$ & $\begin{array}{l}\text { in London } \\
-->\text { in Toronto }\end{array}$ & $\begin{array}{l}\text { at home (in } \\
\text { bed) }\end{array}$ \\
\hline \multicolumn{2}{|c|}{$\begin{array}{l}\text { Typical verbs } \\
\text { of operand } \\
\text { transformation } \\
\text { or of TS-internal } \\
\text { function }\end{array}$} & $\begin{array}{l}\text { convert, } \\
\text { rectify, } \\
\text { oscillate, } \\
\text { process }\end{array}$ & $\begin{array}{l}\text { enlarge } \\
\text { increase, reduce } \\
\text { connect, separate } \\
\text { join, divide } \\
\text { collect, diffuse } \\
\text { combine, dissipate } \\
\text { connect, interrupt } \\
\text { couple, disconnect } \\
\text { emit, absarb } \\
\text { manufacture } \\
\text { produce }\end{array}$ & $\begin{array}{l}\text { conduct, isolate } \\
\text { guide, release }\end{array}$ & $\begin{array}{l}\text { store, retrieve } \\
\text { hold, release } \\
\text { keep, reject }\end{array}$ \\
\hline
\end{tabular}

Figure 3 Basic Classification of Transformation Processes and Technical Processes $[4,5,6]$

Figure 3 shows the transformations that can be applied to the operand, with typical verbs that can describe these transformations. Note that humans and other living things can only act as operand in a transformation process for relatively complex systems. Once this model is understood, a consistent method and methodology to aid creativity [7] for novel designing of technical systems can be proposed.

With this transformation system, designers can (for a novel system to be designed) $[4,5,6]$ :

(0) establish a design specification for the required system, by re-formulating the customers' needs into a full list of requirements as understood by the engineering designer, and by obtaining agreement 
with the customers (or their representative) and the management of the manufacturing organization;

(1) establish the desirable and required output (operand in state $\mathrm{Od} 2$ ) of the transformation, the ultimate purpose of the product;

(2) establish a suitable transformation process to change the operand from state Od1 to state Od2, its operations in detail, investigating possible alternative operations and their sequencing, and (if needed) establishing suitable inputs (operand in state Od1);

(3) decide which of the operations in the transformation process will be performed by humans, and which of them by technical systems, alone or in mutual cooperation;

(4) which technical systems (or parts of them) need to be designed at that point (i.e. do not yet exist);

(5) establish a technology (with possible alternatives) for that transformation operation for which the technical system needs to be designed, and therefore the effects (as outputs) needed from the technical system to cause the transformation;

(6) establish what the technical system needs to be able to do (its internal and cross-boundary functions, with possible alternatives) to produce these effects/outputs, and what its inputs need to be;

(7) establish what organs (function-carriers in principle, with possible alternatives) can perform these functions, and what added functions (and organs) are recognized as needed (a function-means chain). A morphological matrix is useful for exploring candidate organs to solve each function, and to allow combining them into organ structures (as concepts). These organs can be found mainly in prior art, especially the machine elements, in a revised arrangement as proposed by Weber $[8,9]$;

(8) establish with what constructional parts (in sketchoutline, in rough layout, in dimensional-definitive layout, then in detail and assembly drawings, with possible alternatives) are needed, and what additional functions (and organs, and constructional parts) are now revealed (evoked) as being needed (a more extended function-means chaining), to produce a full description of a future TS in the shortest time at lowest cost. Only those parts of this designing process that are thought to be useful are employed.

Redesign can be accomplished by:

(a) establishing a design specification for the revised system (step 0);

(b) analyzing the existing system into its organs and (if needed) its functions (reversing steps (7) and (6) of the novel procedure);

(c) then following the last one or two parts of the procedure listed above for a novel system.

Consideration of life cycle issues is included in the outlined methodology, which necessarily also involves 'Design for $\mathrm{X}$ ' knowledge and advice.

Neither novel design engineering nor re-designing can possibly be done in a linear procedure; feedback, iteration (repeating the operations with better understanding of the problem) and recursion (dividing a problem into smaller parts, solving, then re-combining) are always needed. The possibilities of searching for alternatives is presented in several steps - is this not the essence of creativity? Possible analysis by engineering sciences exist at several stages. Each step should conclude with a cycle of review, including key-words such as 'substantiate', 'evaluate', 'select', 'decide', 'improve', 'optimize', 'verify', 'check' and 'reflect'.

\section{Case Examples}

Examples of the results of using the methodology were shown in [10]. The recommended methodology has meanwhile received several revisions. Two more recent examples are demonstrated.

The first example shows steps in designing a ringlubricated sliding bearing [5,12]. Figure 4 presents (left side) a master design specification (step 0) that needs to be completed by adding required values of variables, and any other contract-specific requirements. The right side shows the effect, technology, action principle (steps 5), function structure (step 6), organ structure (step7), and first layouts (step 8). A method to establish the needed parameters and dimensions for this bearing is shown in figure 5. From this data, a full layout (as a general arrangement) can be developed, as shown in figure $6-$ this diagram is more typical of working on a drawing board, or with a wire-frame computer modeler. Working with a solid-modeling program would be somewhat different.

The second example shows steps in designing a single-reduction spur gear box, figure 7, with some suggestions for details of mounting and sealing the rolling bearings.

Both of these examples refer to relatively conventional machines, the first steps (1-4) of the novel procedure are not absolutely necessary in designing them. Nevertheless, it is sometimes useful to enter into the full procedure, especially if a radical innovation is expected for a portion of the required system.

\section{Closure}

Consequences for an engineering curriculum are mainly $[3,7,11]$ that if students are exposed to design methodology and a supporting body of theory $[4,5,6]$ (not just the mathematics of the engineering sciences), they can develop the ability and skill to use these methods for designing - if they are not so exposed, they can hardly be expected to use design methods, and their skills development for design engineering will be slow. Typically, new graduates need about ten years to become competent engineering designers under traditional education. Education for design engineering using design methodology has shown that this time can be reduced to about five years. Do we need to wonder why engineering graduates choose to be promoted into management positions before they become competent engineering designers?

Exposure to design methodology and theory should occur for the whole attending class, not just by giving separate attention to individual students as they reach a suitable point in their design project work - the separate attention is needed for reinforcement and for 'learning by doing'. Lectures about theory and methodology are needed in addition to supervised projects. 


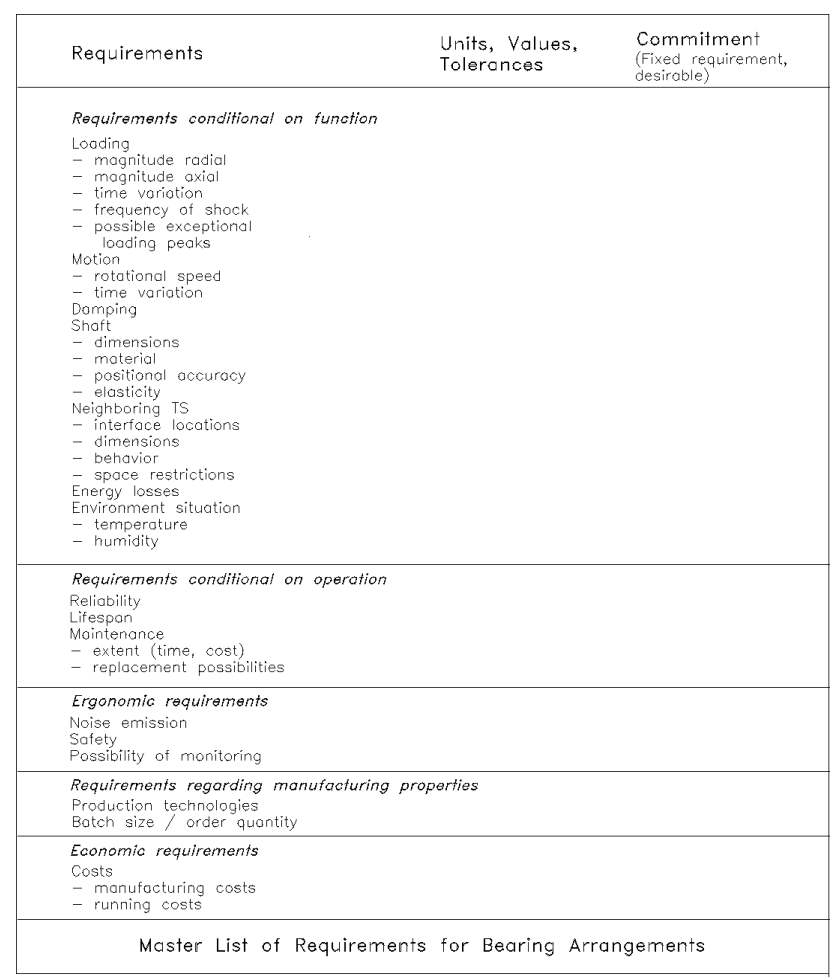

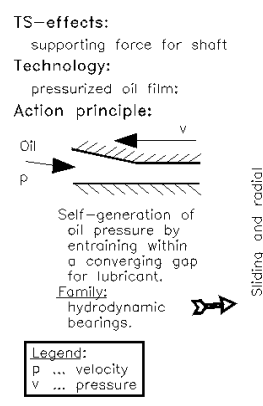

Master Function Structure

Master Organ Structure (Concept)

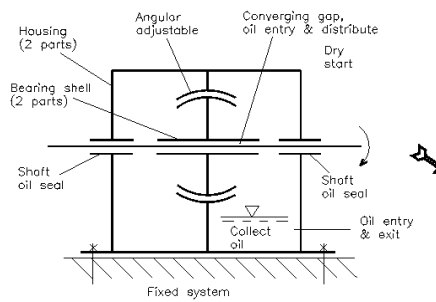

Oil, $q 1, p 1$

Toil, $q 2, p^{2}$

Connecting effect
to fixed system

(react all possible
forces, fix in

Master Preliminary Layout (Constructional Structure -- abstract)
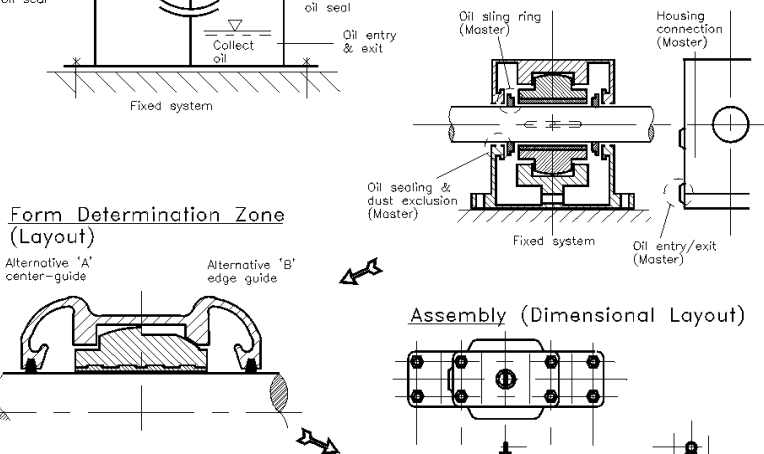

Assembly (Dimensional Layout)

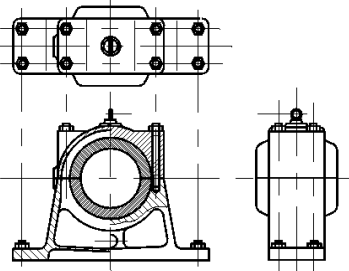

Figure 4 Design Specification, and Typical Structures for a Sliding Bearing [5]

\section{References}

[1] ISO9000:2000, ISO 9000 Quality Management Systems - Requirements, Geneva: ISO

[2] Eder, W.E. and Hosnedl, S. (2004) 'Information - a Taxonomy and Interpretation', in Proc. International Design Conference - Design 2004, Dubrovnik, May 18 - 21, 2004, p. 169-176.

[3] Eder, W.E., Hubka, V. and Benabdallah, H. (2004) 'Educating for Engineering Design using Design Science', Proc. Inaugural CDEN Design Conference, McGill University, Montreal, July 29-30, 2004, on CDROM

[4] Hubka, V. and Eder, W.E. (1992) Engineering Design (Zürich, Heurista)

[5] Hubka, V., \& Eder, W.E. (1996) Design Science: Introduction to the Needs, Scope and Organization of Engineering Design Knowledge (London: SpringerVerlag) http://deed.ryerson.ca/DesignScience/

[6] Hubka, V. and Eder, W.E. (1988a) Theory of Technical Systems (Berlin/Heidelberg \& New York, SpringerVerlag)

[7] Eder, W.E. (ed) (1996) WDK 24 - EDC - Engineering Design and Creativity - Proceedings of Workshop EDC (Zürich, Heurista)

[8] Weber, C. and Vajna, S. (1997) 'A New Approach to Design Elements (Machine Elements)’, in WDK 25 -
Proc. ICED 97 Tampere, Tampere University, Vol. 3, p. $685-690$

[9] Eder, W.E. (2005) 'Machine Elements - Revision and Outlook for Design Education', in press for Proc. Second CDEN International Conference, University of Calgary, 18-19 July 2005

[10] Hubka, V., Andreasen, M.M. and Eder, W.E. (1988b) Practical Studies in Systematic Design (London, Butterworths)

[11] Eder, W.E., Hubka, V., Melezinek, A. \& Hosnedl, S. (1992) WDK 21 - ED - Engineering Design Education - Ausbildung der Konstrukteure - Reading (Zürich: Heurista)

[12] Leyer, A., Machine Design, Glasgow: Blackie, 1974 


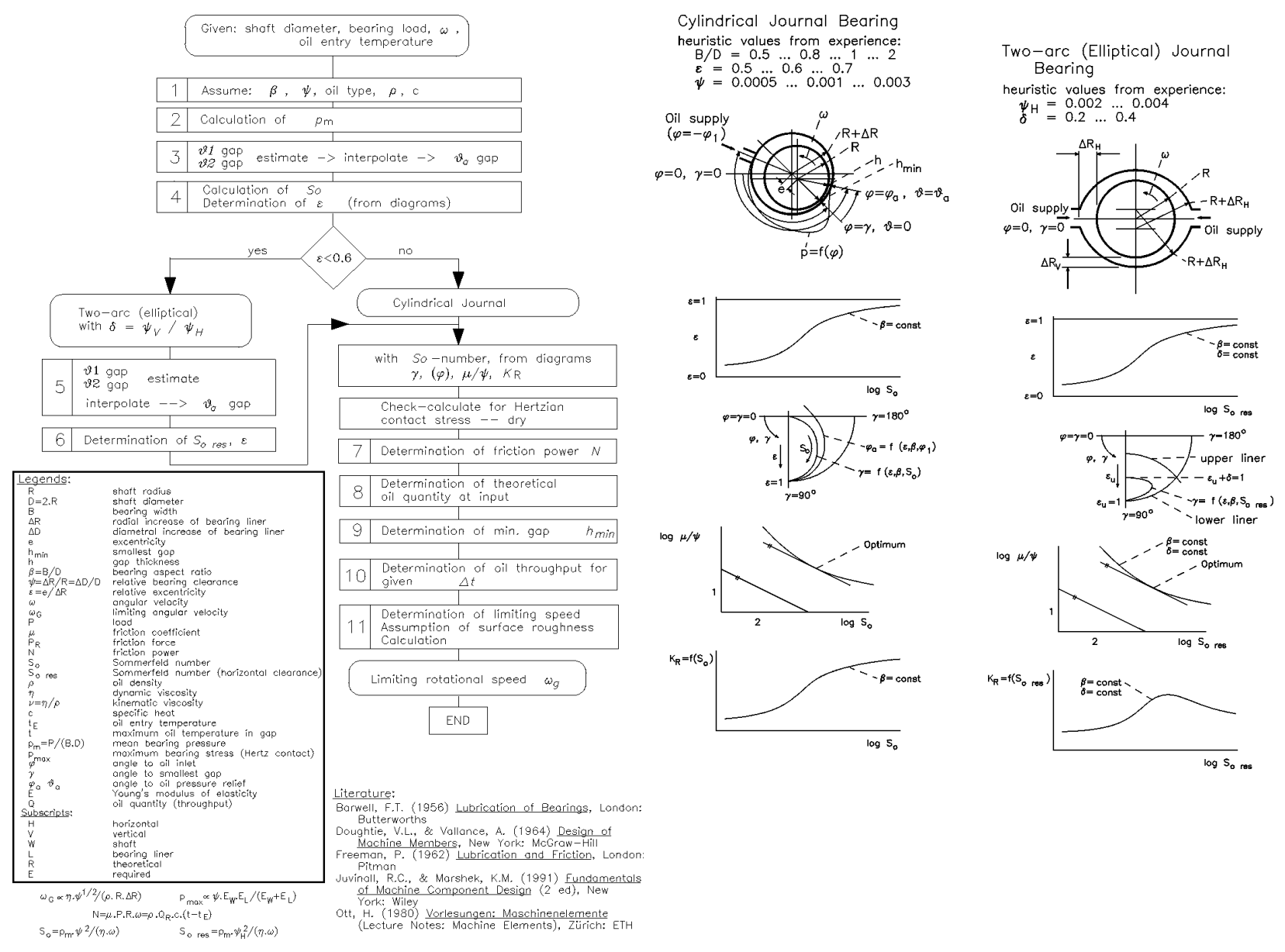

Figure 5 Method for Parameter Designing for a Sliding Bearing [5]

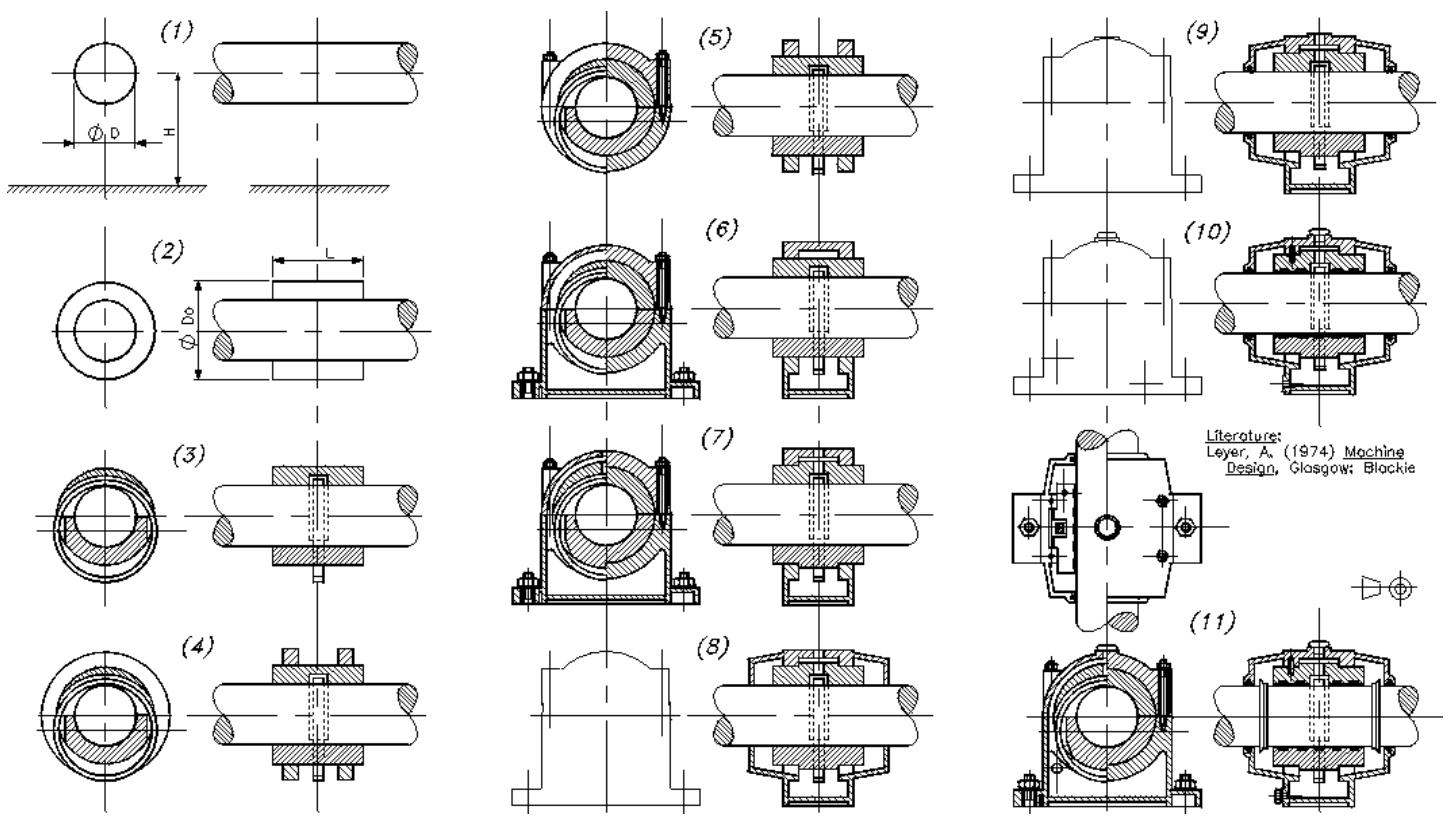

Figure 6 General Arrangement Drawing for a Ring-Lubricated Sliding Bearing [5,12] 


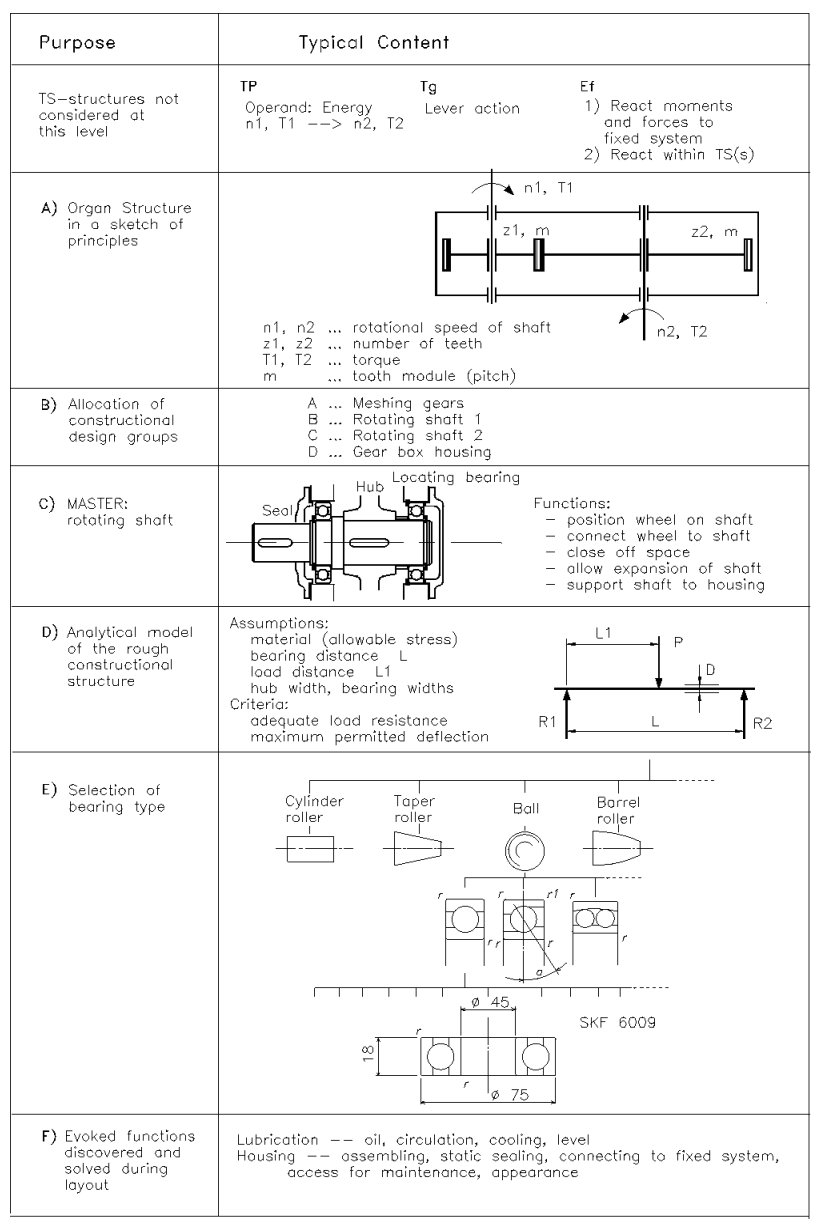

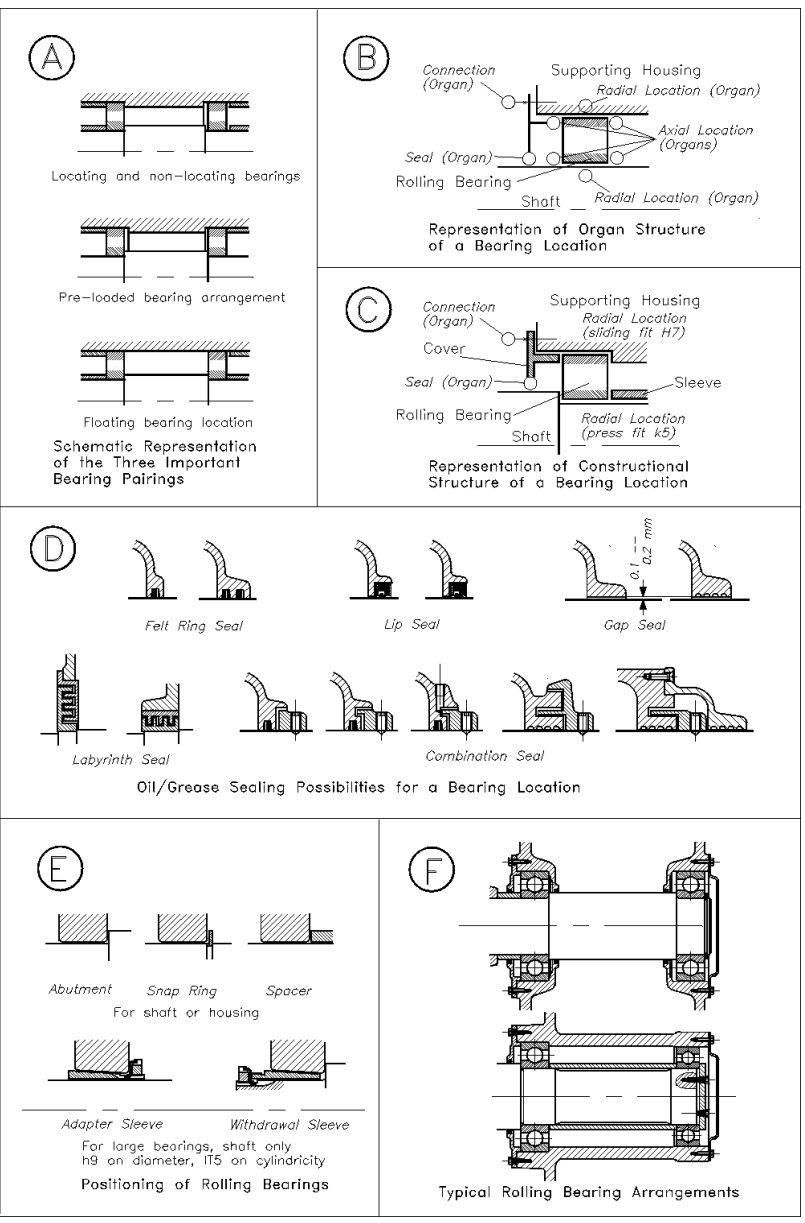

Figure 7 Steps and Master Details of Arrangement for a Spur Gear Box [5] 